\title{
Confrontation between Supply and Demand for Voluntary Information in the Annual Reports in an Emerging Country: The Tunisian Case
}

\author{
Raïda CHAKROUN \\ Department of Accounting, Law \& Taxation \\ High Institute of Business Administration (University of Sfax, Tunisia) \\ E-mail Address: raida_c@yahoo.fr $\quad$ Tel: (+216) 98953605
}

Received: October 25, 2012 Accepted: December 10, 2012 DOI: 10.5296/ijafr.v2i2.2564

\begin{abstract}
In this paper, we compare the usefulness of 72 items of voluntary information of 40 Tunisian Financial Analysts and Portfolios Managers (TFAPM) and the degree of their disclosure in the annual reports (AR) of 24 companies listed on the Stock Exchange Securities of Tunisia (SEST). It is an extension of the work of (Myburgh, 2001; McNally et al. 1982; Buzby, 1974). The results show that the voluntary information content of the (AR) does not meet the informational needs of the (TFAPM). More specifically, the provision (i.e. supply) of 29 items in the (AR) diverges completely with their application (i.e. demand) by the (TFAPM). Most of these items are items whose disclosure is voluntary and not closely linked to the mandatory one. However, the results reveal that the majority of the 9 items, for which the offer in the (AR) and the demand of the (TFAPM) converge, are items whose disclosure is voluntary and closely linked to the mandatory one.
\end{abstract}

Keywords: supply, demand, voluntary information, annual reports, financial analysts and portfolio managers 


\section{Introduction}

The need of investors and financial analysts for voluntary information has been varied and refined. This information helps investors evaluate their heritage and decide when to buy, keep or sell the securities of the company in question (Healy and Palepu, 2001). Therefore companies must face this intense and growing need for information on the part of all the users of these annual reports. This need vary among the countries due to the institutional factors specific to each country (Ball et al., 2000). These authors hypothesize that international differences in legal and institutional factors contribute to differences in the demand for accounting information, and this causes predictable international variability in accounting standards and the properties of accounting numbers.

The studies conducted on emerging economies of (Barako et al., 2006; Ho and Wong, 2004; Ho and Wong, 2001; Myburgh, 2001; Michailesco, 2000) as well as those conducted on developed economies of (Clarkson et al., 1999; Prencipe, 2004; Raffournier, 1995), support the idea that knowing the company's choice of economic disclosure influences the assessment of its value by financial market participants. Moreover, in order to keep communication going, the language used must be that of the receiver. Voluntary disclosure borrows from the marketing approaches. More specifically, it is for the company to "sell" its image in the market as well as to convey financial and accounting information (Leger, 2003).

The studies of (Naser and Nuseibeh, 2003; Ho and Wong, 2001) conducted on emerging economies have shown the existence of an informational gap between the voluntary information disclosed in the annual reports and the one needed by the users. At this point, (Khlifi and Bouri, 2010) conclude that it is more suitable to mobilize different theoretical foundations to explain the phenomenon of voluntary disclosure since there isn't a theory specifically designed to explain it. We notice that some listed Tunisian companies do not grasp this information as a real means of economic disclosure (Nekhili and Fakhfakh, 2008). We also notice that the stakeholders in companies have a real crisis of confidence manifested by an intense need for information (Yaich, 2006). These findings lead us to set the following research question: to what extent does the supply of voluntary information in the annual reports of the companies listed on the (SEST) meet the information demand (or needs) of the Tunisian financial analysts?

The main objective of this paper is to underline the degree of adequacy of voluntary information disclosed in the annual reports with the perception of its usefulness by financial analysts. Voluntary information that we are interested in is justified in our current economic context (financial scandals, growing market volatility) since it shows the limitations of the accounting information submitted by the study of (Al-Razeen and Karbhari, 2007) about Saudi Arabia and that of (Chow and Wong-Boren, 1987) about Mexico. Like (Myburgh, 2001; McNally et al., 1982; Buzby, 1974), we are interested in the phenomenon of voluntary disclosure in a double dimension (supply and demand). This two-dimensional approach tends to compare the voluntary information needs of the external users of the annual reports concerning their disclosure in these reports.

The choice of the Tunisian case is made due to the fact that the economic and legal 


\section{Mll Macrothink}

International Journal of Accounting and Financial Reporting ISSN 2162-3082 2012, Vol. 2, No. 2

environment of this country has undergone major changes in the recent years. This is clearly reflected mainly in the promulgation of Act $n^{\circ} 2005-96$ on to the strengthening of the financial security, by the publication of the Arab Institute of Business Leaders of a guide of good corporate governance practice in 2008, and the guide of the annual report of the Tunisian enterprises in 2009; as well as the establishment of the Tunisian Center of Corporate Governance in 2009. It should be noted that Tunisia is an African developing country of the MENA zone, having an emerging stock market, where the minority shareholders are not well protected and the economic disclosure is a weakly regulated field. Kothari (2000) argue that if enforcement of shareholder rights and disclosure standards is weak, then the quality of disclosure tends to be poor, regardless of the disclosure standards.

Information disclosure in the management annual report is a kind of information presentation which is not yet strictly regulated, the thing which makes the research useful in this area. Indeed, the voluntarily information disclosed today is likely to be required tomorrow. In this way, Tunisia is experiencing a progressive harmonization with the international financial reporting standards (IFRS) that will result in a switch toward these standards in 2014. This move toward the international standards is a real upheaval in the financial information guideline of the company and aims to adopt a common and internationally recognized financial language.

The review of the previous studies on the phenomenon of voluntary disclosure enabled us to see that their number in the emerging financial markets is relatively small. The contributions of this research are essentially of a contextual and conceptual nature. Firstly, on the contextual level, we will adapt the (Botosan, 1997) index to Tunisia. Secondly, we propose to compare voluntary disclosure provided in the annual reports with the one required by the external users of these reports, the thing which was not previously carried out in the Tunisian context. On the conceptual level, we will define two voluntary information sub index: the sub index of voluntary disclosure closely linked to the mandatory one and that of voluntary disclosure not closely linked to the mandatory one.

This research paper is organized as follows: the second section will be devoted to the presentation of the literature review and the theoretical basis. The methodology will be presented in the third section. The fourth section will deal with the empirical results obtained. Finally, the fifth section will be the conclusion.

\section{Challenge of matching voluntary information supply in the annual reports upon request}

The annual reports preparers must provide the users of these reports with the relevant information concerning the decision making. In this way, the annual reports must be prepared according to the needs of the external users (Ball et al., 2000). We first present the regulatory framework of the management annual report in Tunisia. Second, we focus on voluntary disclosure as a tool of financial marketing. Third, we review some studies about the comparison between supply and demand for voluntary information in the annual reports. 


\subsection{Regulatory framework of the management annual report in Tunisia}

We distinguish the mandatory disclosure required by strict legal procedures from the voluntary disclosure (non mandatory or optional) which is the initiative of the company's leaders (Healy and Palepu, 2001).

In Tunisia, the legal obligations for the annual reports are set by the Code of Commercial Companies (which have a field of application covering most of the trading companies), the Tunisian firms' accounting system and the regulation of the Financial Market Council (of which the fields of application extend to all the companies publicly appealing to savings). Unlike the financial statements which have an expanding legal basis and in a continuous evolution, there are no similar norms governing firms' complementary information which are to be presented in the management annual report.

The article 201 of the Code of Commercial Companies (CCC) gives no precision about the form and content of the management annual report, but only about the fact that it must be "detailed". In addition, The Tunisian firms' accounting system (1997) has given no precisions about the information to be provided concerning the management annual report. In this way, the conceptual framework of the Tunisian accounting highlights, in its paragraph 83, the importance of information which goes beyond the financial dimension to reach other dimensions such as the social, ecological, as well as the technological dimension. Only Article 44 of the Regulation of the Financial Market Council (FMC), which relates to public offering approved by the April 7, 2000 order of the finance minister, lists the mandatory information to be provided in the management annual report.

\subsection{Voluntary disclosure: an essential tool of financial marketing}

Companies can fine-tune their supply of voluntary disclosure to supplement mandated disclosure in order to meet investors' demand (Kothari, 2000). Seekers of accounting information are turning towards standardized and mandatory information. However, this type of information has some deficiencies: rigidity of the rules and deficiencies inflicted by some principles...To exceed the statutory accounting model; these actors would be looking for useful complements (Schuster and O'Connell, 2006). Therefore, a leader must permanently give and restore confidence to shareholders that it becomes possible to assimilate to customers for the product action of the company. According to (Leger, 2003), like any marketing approach that is any advocacy and seduction work of the demand by the supply, economic disclosure must be a rational and formalized approach on the part of the company. As a result, the company must speak out more, attract attention and convince to have its shares sold. Nevertheless, we should point out that no Tunisian company was punished for its non compliance with the compulsory notices set by legislation.

According to the open market approach, the information disclosed by the company must be processed the same way as the other goods (May and Sunden, 1976). We notice a great similarity between the commercial marketing approach and the financial marketing one. While continuing with this analogy, it is interesting to define the most important element of financial marketing mix, namely the product. The latter is the company as a whole 
represented by its shares. Therefore, the supply and demand forces must lead to an optimal supply of information.

\subsection{Voluntary information demand versus its supply in the annual reports}

In a meta-analysis ${ }^{1}$, Courtis (1992) synthesized the results of 11 previous studies on the perception of the importance of 63 items. This study was conducted on six countries over a 16- year- period. Among its main results:

-The preparers and users of the annual reports agree on the importance of almost $30 \%$ of the items.

- Financial analysts give importance to the disclosed items more than the preparers of the annual reports do.

- For the users of the annual reports, the perception averages of the importance of the items by the financial analysts, the bank credit managers and the accountants are significantly different from those of the investors.

Ball et al. (2000) argue that the informativeness of required accounting varies systematically with firm and country characteristics.

On the one hand, the studies of (Buzby, 1974; Prencipe, 2004) were conducted on developed markets. Firstly, the study of Buzby (1974) is based on a list of 38 financial and non-financial items. The results of this study indicate that many items, which are considered important by the analysts, are not appropriately disclosed by the companies of the sample (88 SME) and there is a weak correlation between the importance attached by the analysts to the items and the level of their disclosure in the annual reports. Secondly, the study of Prencipe (2004) is based on nine sector-based items which have voluntary disclosure. By comparing the number of companies which disclose the item with the weight assigned to it by the financial analysts, this study pointed out that the gap between information supply and demand is very clear for the three following items: the operational results, the segment assets and the capital expenditure. This difference arises because these items are disclosed by a very small number of companies despite their strong utilities for the financial analysts.

On the other hand, the studies of (Myburgh, 2001; McNally et al., 1982) were conducted on developing markets. First, the results of the study of Myburgh (2001) confirm the existence of a discrepancy between the perceptions of the users and those of the producers of the annual reports for 17 items out of the 49 items analyzed which are voluntarily disclosed in South Africa. Then McNally, et al., (1982) have linked the level of importance attached by the users of the annual reports (financial publishers and members of the scholarship) to the items of information with the level of disclosure by the companies listed in New Zealand. The results of this study indicate that the discrepancy between the perception of financial analysts and the companies' disclosure practices holds for most of 41 studied items.

According to what was mentioned above, we propose to test the following hypothesis.

\footnotetext{
${ }^{1}$ It is a methodology used in social science with the main objective the synthesis of the results of the previous different studies with deal with the same thing.
} 


\section{Macrothink}

International Journal of Accounting and Financial Reporting

Hypothesis: There is a discrepancy between the usefulness of voluntary information perceived by financial analysts and the degree of disclosure in the annual reports.

\section{Investigation method}

First, we present the samples and the data. Next, we present the variables and their measures and finally we highlight the strategy of hypothesis testing.

\subsection{Sample selection and data collection}

Our study is based on a primary data collection from questionnaires conducted next to the population of financial analysts and portfolio managers who work on behalf of the brokers in Tunisia $^{2}$, as well as on secondary data from the annual reports of companies listed on the Stock Exchange Securities of Tunisia (SEST).

\subsubsection{Sample of financial analysts and portfolio managers}

Our choice to focus on this particular category of users of the annual reports was made for several reasons: the importance of these users' intermediary role in the chain of economic information, their ability to rationally explain their specific needs for information and their capacity to guide the investors' behavior in the financial market (Healy and Palepu, 2001). However, it should be noted that the job of the financial analyst in Tunisia has not stopped improving in the recent years, especially after the creation of the Tunisian Association of Financial Analysis in 2008 (Official Journal No. 12; February 8, 2008).

We have directly circulated 62 questionnaires to the sell-side financial analysts and portfolio managers' population working on behalf of 24 stockbrokers $^{3}$ in May and June 2007. We got responses of 40 sell-side financial analysts and portfolio managers who working on behalf of 21 stockbrokers representing $87.50 \%$ of the stockbrokers in the (SEST). We obtained a response rate of $64.51 \%$. The sample size, about which this study, is similar to the study sample of Prencipe (2004) which consists of 56 financial analysts. Table 1 presents a summary of sample of the respondent's characteristics.

The data were extracted from the responses of our sample. The respondents were asked to express the degree of usefulness they attach to voluntary items of information included in our grid (see Appendix1).

\footnotetext{
2 The stockbrokers in the (SEST) are either legal or natural people who have the monopoly of recording and negotiating the securities in (SEST). Their main job is to transmit the orders to buy or sell the securities of their customers in the stock market.

${ }^{3}$ We have contacted 24 stockbrokers in the (SEST) who were there when we carried out inquest.
} 
Table 1. Characteristics of the respondents' sample

\begin{tabular}{|c|c|c|c|}
\hline \multicolumn{2}{|c|}{ Characteristics of the respondents } & Number & Frequency (in \%) \\
\hline \multirow{2}{*}{ Function } & Financial Analyst & 32 & 80 \\
\hline & Portfolio Manager & 8 & 20 \\
\hline \multirow{2}{*}{$\begin{array}{l}\text { Number of annual } \\
\text { reports read } \\
\text { (by average) }\end{array}$} & Less than 30 & 19 & 47,5 \\
\hline & More or equal to 30 & 21 & 52,5 \\
\hline \multirow{3}{*}{ Diploma } & $\begin{array}{l}\text { Bachelor of Arts } \\
\text { (BA) }\end{array}$ & 15 & 37,5 \\
\hline & Master of Arts (MA) & 24 & 60 \\
\hline & $\mathrm{PhD}$ & 1 & 2,5 \\
\hline \multirow{4}{*}{ Specialty } & Accounting & 3 & 7,5 \\
\hline & Management & 8 & 20 \\
\hline & Finance & 28 & 70 \\
\hline & Economy & 1 & 2,5 \\
\hline \multirow{3}{*}{$\begin{array}{l}\text { Professional } \\
\text { experience }\end{array}$} & Less than 5 years & 17 & 42,5 \\
\hline & $\begin{array}{c}\text { Between } 5 \text { and } 10 \\
\text { years }\end{array}$ & 12 & 30 \\
\hline & More than 10 years & 11 & 27,5 \\
\hline
\end{tabular}

\subsubsection{Company Sample}

The sample consists of companies listed on (SEST). It appears relevant to focus on the listed companies that are careful about their disclosure policy and more specifically about the informational content of their management annual reports. The sample is limited to all companies of the non-financial sector, and this is similar to what was stated by (Hassan, Giorgioni and Romilly, 2006; Hasnan, 2005; Leventis and Weetman, 2004; Naser and Nuseibeh, 2003; Depoers, 2000), due to the specificity of the financial disclosure of the banking sector and that of the financial services and insurance.

Since the survey of the financial analysts and portfolio managers was conducted during the first half of 2007, the annual reports analyzed for the degree of the disclosed items are those of 2005. Actually, the 2006 annual reports were not yet at hand during the survey period for the majority of the financial analysts and portfolio managers. Our sample consists of 24 firms observed during 2005, represents all the companies listed on (SEST) of the non-financial sector. Collecting the Tunisian companies' annual reports was not an easy task because these reports are not directly downloadable via the internet. Almost all the annual reports were photocopied from the (FMC) and from the stockbrokers. Table 2 shows a distribution of company sample by sector of activity.

The data were extracted from the annual reports of companies in our sample. The methodology consists in reading the annual reports and comparing the information presented in them with that on the grid of voluntary items. 
Table 2. Distribution of company sample by sector of activity

\begin{tabular}{|c|c|c|}
\hline Sector of activity & Companies & Codes \\
\hline TELECOMMUNICATIONS & $\begin{array}{lrrr}\text { SOCIETE } & \text { TUNISIENNE } & \text { D'ENTREPRISES } & \text { DE } \\
\text { TELECOMMUNICATIONS } & & \end{array}$ & SOTET \\
\hline \multirow{3}{*}{ CONSUMER SERVICES } & MAGASIN GENERAL & MAG \\
\hline & $\begin{array}{l}\text { SOCIETE NOUVELLE MAISON DE LA VILLE DE } \\
\text { TUNIS }\end{array}$ & MNP \\
\hline & SOCIETE TUNISIENNE DES MARCHES DE GROS & MGR \\
\hline \multirow{3}{*}{ TRAVEL AND LEISURE } & SOCIETE TUNISIENNE DE L'AIR & TAIR \\
\hline & KARTHAGO AIRLINES & KAIR \\
\hline & PALM BEACH HOTELS TUNISIA & PBHT \\
\hline HEALTH & $\begin{array}{l}\text { SOCIETE DES INDUSTRIES PHARMACEUTIQUES DE } \\
\text { TUNISIE }\end{array}$ & SIPHA \\
\hline \multirow{4}{*}{ CONSUMER GOODS } & SOCIETE L'ACCUMULATEUR TUNISIEN & ASSAD \\
\hline & $\begin{array}{llll}\text { SOCIETE } & \text { GENERALE } & \text { INDUSTRIELLE } & \text { DE } \\
\text { FILTRATION } & & & \end{array}$ & GIF \\
\hline & SOCIETE TUNISIENNE D’EQUIPEMENT & STEQ \\
\hline & $\begin{array}{lcccc}\text { SOCIETE } & \text { TUNISIENNE } & \text { DES } & \text { INDUSTRIES } & \text { DE } \\
\text { PNEUMATIQUES } & & & \\
\end{array}$ & STIP \\
\hline \multirow{2}{*}{ FOOD AND DRINKS } & SOCIETE FRIGORIFIQUE ET BRASSERIE DE TUNIS & SFBT \\
\hline & TUNISIE LAIT & TLAIT \\
\hline $\begin{array}{l}\text { HOUSEHOLD } \\
\text { PRODUCTS AND } \\
\text { PERSONAL CARE }\end{array}$ & ELECTROSTAR & LSTR \\
\hline \multirow{3}{*}{$\begin{array}{l}\text { BUILDINGS AND } \\
\text { BUILDING MATERIALS }\end{array}$} & SOCIETE IMMOBILIERE ET DE PARTICIPATION & SIMPAR \\
\hline & SOCIETE IMMOBILIERE TUNISO-SEOUDIENNE & SITS \\
\hline & SOCIETE MODERNE DE CERAMIQUE & SOMOC \\
\hline \multirow[t]{2}{*}{$\begin{array}{l}\text { INDUSTRIAL } \\
\text { AND SERVICES }\end{array}$} & $\begin{array}{l}\text { SOCIETE INDUSTRIELLE D'APPAREILLAGE ET DE } \\
\text { MATERIELS ELECTRIQUE }\end{array}$ & SIAME \\
\hline & SOCIETE TUNISIENNE DE VERRERIES & SOTUV \\
\hline \multirow{3}{*}{ CHEMISTRY } & AIR LIQUIDE TUNISIE & $\mathrm{AL}$ \\
\hline & SOCIETE CHIMIQUE & ALKIM \\
\hline & SOCIETE DES INDUSTRIES CHIMIQUES DU FLUOR & $\mathrm{ICF}$ \\
\hline OIL AND GAS & $\begin{array}{l}\text { SOCIETE DE TRANSPORT DES HYDROCARBURES } \\
\text { PAR PIPELINES }\end{array}$ & STPIL \\
\hline
\end{tabular}

3.2 Definitions and measures of variables

At first, we present our grid of voluntary items, then the definitions and measures of the variables: the perceived usefulness of the item, its average score and degree of disclosure. 


\subsubsection{The grid of voluntary items}

We constructed an index of voluntary disclosure by relying on the Botosan (1997) index, which is structured around five categories of information. We have removed 8 items because they are not disclosed by any company in our sample and we added three categories of information: information on the intangibles, social and environmental information and information on corporate governance. These categories of information, as their usefulness has been demonstrated by the previous literature, are added so as to rectify the shortcomings of the Botosan (1997) index. The grid of voluntary items is documented in Appendix1. In addition, we classify the items of our grid into two sub-indexes:

- The first sub-index consists of the items which have a voluntary disclosure closely linked to mandatory one. The disclosure of these items is mandatory under the Article 44 of the (FMC) Regulation relating to the public offering. This index, which represents the legally required information for the companies making public offerings, is composed of 23 items.

It is to be announced that no Tunisian company was sanctioned for its failure to comply with mandatory information envisaged by the legislation. All the information included in the management annual report has the vocation of volunteers, others that those included in the financial statements, the auditors' certificates and in the resolutions of the annual assembly.

- The second sub-index integrates the items which have a voluntary disclosure not closely linked to the mandatory one. In other words, they are the items with a disclosure not required by any regulation in Tunisia and which have no connection with the mandatory disclosure. This sub-index consists of 49 items.

\subsubsection{The UPA variable: "usefulness perception of the item" (demand)}

In our study, the survey respondents were asked to give their opinion about how useful the items in the analysis grid are by assigning a score on a five-point Likert scale (from $1=$ not useful to $5=$ very useful). This approach is to assign each item a weight reflecting its utility according to the chosen group of the users of annual reports. The usefulness perception of the item (UPA) is the average weight of each item (it is the sum of points assigned by the respondents to the item divided by the number of the respondents). This measure was used by (Prencipe, 2004; McNally et al., 1982; Buzby, 1974).

$\mathrm{UPA}=\Sigma$ Points assigned by the respondents to the item / Number of respondents

\subsubsection{The disclosure average score of the item (supply)}

The disclosure average score of each item is the sum of the points assigned to it, according to the annual reports coding, divided by the number of the companies likely to disclose it. With reference to Buzby (1974), a careful examination of the content of the companies' annual reports of our sample will help us assign points to the various items as follows:

-For the first group of items: These items can be disclosed only in a quantitative form. If the item is disclosed we will give it its average weight and if the item is not disclosed we will give it "0". 


\section{MlMacrothink}

International Journal of Accounting and Financial Reporting

ISSN 2162-3082

2012, Vol. 2, No. 2

-For the second group of items: These items may be disclosed in different forms (quantitative and qualitative). If the item is disclosed with a quantitative indication, we will give it its average weight. If it is divulged with a qualitative indication, we give it only half of its average weight and if the item is not disclosed we will give it "0".

Average disclosure score $=\Sigma$ Points assigned to the item according to the annual reports coding / Number of the companies likely to disclose the item

\subsubsection{The DDS variable: "degree of the item disclosure" (supply / demand)}

We will apply a measure inspired by the one adopted by (Buzby, 1974; Michailesco, 1999). The disclosure degree of each item is measured by the average score of its disclosure in the companies likely to disclose it (which corresponds to the supply of the item) divided by the average weight of the item (or UPA which corresponds to the demand of the item).

$$
\text { DDS }=(\text { Average disclosure score of the item / UPA of the item }) * 100
$$

\subsection{Hypothesis testing strategy}

This is to compare and analyze the numbers found. Like (Naser and Nuseibeh, 2003; Depoers, 1998; McNally et al., 1982; Buzby, 1974), we focus on the level of disclosure of the single items forming the grid of the voluntary ones (through the determination of the number of the firms that disclose the item compared to the ones likely to disclose it). This will help us determine the items the most and the least disclosed by the companies of our sample.

Like Prencipe (2004), we compare the percentage of the firms disclosing the items (their supply) to their average weight (their demand). We also compare the rank of the items according to their perceived usefulness (classification of items according to the UPA variable) and to their rank according to the degree of disclosure (classification of items according to the variable DDS). Following the methodology of Buzby (1974), we study the relationship between these two variables (the two classifications of items) through the Spearman correlation coefficient.

Finally we calculate the overall degree of voluntary disclosure for all the items. It is the weighted average of the DDS variable and the weights corresponding to the number of companies about which the item is likely to be disclosed.

\section{Analysis and discussion of the empirical results}

We first present the scope of supply and demand for voluntary information in annual reports. Then, secondly we outline the convergences and divergences between supply and demand for voluntary information in annual reports. Finally, thirdly we present a synthesis of empirical findings.

\subsection{Scope of voluntary information supply and demand in the annual reports}

4.1.1 Scope of voluntary information demand in the annual reports 
Table 3. Demand of voluntary information in annual reports

\begin{tabular}{|c|c|c|c|c|}
\hline Items & UPA & $\begin{array}{l}\text { Classification } \\
\text { according to } \\
\text { the UPA }\end{array}$ & $\begin{array}{l}\text { Minimum } \\
\text { weight }\end{array}$ & $\begin{array}{l}\text { Maximum } \\
\text { weight }\end{array}$ \\
\hline \multicolumn{5}{|l|}{ 1. Background Information } \\
\hline $\begin{array}{l}\text { 1.A statement of corporate goals or } \\
\text { objectives is provided }\end{array}$ & 4.33 & 18 & 2 & 5 \\
\hline $\begin{array}{l}\text { 2.A general statement of corporate strategy } \\
\text { is provided }\end{array}$ & 4.50 & 9 & 3 & 5 \\
\hline $\begin{array}{l}\text { 3. Actions taken during the year to achieve } \\
\text { the corporate goals are discussed }\end{array}$ & 4.25 & 26 & 3 & 5 \\
\hline $\begin{array}{l}\text { 4.Planned actions to be taken in future years } \\
\text { are discussed }\end{array}$ & 4.47 & 11 & 3 & 5 \\
\hline $\begin{array}{l}\text { 5.A time frame for achieving corporate } \\
\text { goals is defined }\end{array}$ & 4.25 & 26 & 3 & 5 \\
\hline 6.Barriers to entry are discussed & 3.80 & 57 & 2 & 5 \\
\hline $\begin{array}{l}\text { 7.Impact of barriers to entry on current } \\
\text { profits are discussed }\end{array}$ & 3.85 & 55 & 2 & 5 \\
\hline 8.The competitive environment is discussed & 4.53 & 6 & 2 & 5 \\
\hline $\begin{array}{l}\text { 9.The impact of competition on current } \\
\text { profits is discussed }\end{array}$ & 4.35 & 16 & 2 & 5 \\
\hline $\begin{array}{l}\text { 10.The impact of competition on future } \\
\text { profits is discussed }\end{array}$ & 4.50 & 9 & 2 & 5 \\
\hline $\begin{array}{l}\text { 11.A general description of the business is } \\
\text { provided }\end{array}$ & 3.88 & 50 & 2 & 5 \\
\hline $\begin{array}{l}\text { 12.The principal products produced are } \\
\text { identified }\end{array}$ & 3.98 & 42 & 2 & 5 \\
\hline $\begin{array}{l}\text { 13.Specific characteristics of these products } \\
\text { are described }\end{array}$ & 3.75 & 60 & 2 & 5 \\
\hline 14.The principal markets are identified & 4.30 & 22 & 2 & 5 \\
\hline $\begin{array}{l}\text { 15.Specific characteristics of these markets } \\
\text { are described }\end{array}$ & 4.13 & 36 & 2 & 5 \\
\hline \multicolumn{5}{|l|}{ 2. Summary of historical results } \\
\hline $\begin{array}{l}\text { 16.Return-on-assets or sufficient } \\
\text { information to compute return-on-assets (i.e. } \\
\text { net income, tax rate, interest expense and } \\
\text { total assets) is provided }\end{array}$ & 4.33 & 18 & 2 & 5 \\
\hline $\begin{array}{l}\text { 17.Net profit margin or sufficient } \\
\text { information to compute net profit margin }\end{array}$ & 4.32 & 19 & 2 & 5 \\
\hline
\end{tabular}




\begin{tabular}{|l|l|l|l|l|}
\hline $\begin{array}{l}\text { (i.e. net income, tax rate, interest expense } \\
\text { and sales) is provided }\end{array}$ & & & \\
\hline $\begin{array}{l}\text { 18.Asset turnover or sufficient information } \\
\text { to compute asset turnover (i.e. sales and } \\
\text { total assets) is provided }\end{array}$ & 3.95 & 46 & 2 & 5 \\
\hline $\begin{array}{l}\text { 19.Return-on-equity or sufficient } \\
\text { information to compute return-on-equity } \\
\text { (i.e. net income and stockholders equity) is } \\
\text { provided }\end{array}$ & 4.22 & 30 & 2 & 5 \\
\hline $\begin{array}{l}\text { 20.A summary of sales and net income for at } \\
\text { least the most recent eight quarter is } \\
\text { provided }\end{array}$ & 4.22 & 30 & 2 & 5 \\
\hline
\end{tabular}

\section{Key non-financial statistics}

\begin{tabular}{|c|c|c|c|c|}
\hline 21.Number of employees & 3.58 & 65 & 1 & 5 \\
\hline 22.Order backlog & 3.92 & 47 & 1 & 5 \\
\hline $\begin{array}{l}\text { 23.Percentage of order backlog to be } \\
\text { shipped next year }\end{array}$ & 4.23 & 27 & 2 & 5 \\
\hline $\begin{array}{l}\text { 24.Percentage of sales in products designed } \\
\text { in the last five years }\end{array}$ & 3.95 & 46 & 2 & 5 \\
\hline 25.Market share & 4.60 & 3 & 3 & 5 \\
\hline 26.Amount of new orders placed this year & 4.15 & 34 & 2 & 5 \\
\hline 27.Units sold & 4.10 & 37 & 2 & 5 \\
\hline 28.Unit selling price & 3.78 & 59 & 2 & 5 \\
\hline 29.Growth in units sold & 4.08 & 38 & 1 & 5 \\
\hline 30.Production lead time & 3.65 & 63 & 1 & 5 \\
\hline $\begin{array}{l}\text { 31.Sales growth in key regions not reported } \\
\text { as geographic segments }\end{array}$ & 3.85 & 55 & 1 & 5 \\
\hline 32. Volume of materials consumed & 3.70 & 61 & 2 & 5 \\
\hline 33.Price of materials consumed & 3.95 & 46 & 2 & 5 \\
\hline $\begin{array}{l}\text { 34.Growth in sales of key products not } \\
\text { reported as product segments }\end{array}$ & 3.98 & 42 & 2 & 5 \\
\hline
\end{tabular}

\section{Projected information}

\begin{tabular}{|c|c|c|c|c|}
\hline $\begin{array}{l}\text { 35.A comparison of previous earnings } \\
\text { projections to actual earnings is provided }\end{array}$ & 4.45 & 13 & 3 & 5 \\
\hline 36.A comparison of previous sales & 4.47 & 11 & 3 & 5 \\
\hline
\end{tabular}




\begin{tabular}{|c|c|c|c|c|}
\hline projections to actual sales is provided & & & & \\
\hline $\begin{array}{l}\text { 37. The impact of opportunities available to } \\
\text { the firm on future sales or profits }\end{array}$ & 4.20 & 31 & 2 & 5 \\
\hline $\begin{array}{l}\text { 38. The impact of risks facing the firm on } \\
\text { future sales or profits is discussed }\end{array}$ & 4.27 & 24 & 2 & 5 \\
\hline 39. A forecast of market share is provided & 4.35 & 16 & 2 & 5 \\
\hline 40.A cash flow projection is provided & 4.13 & 36 & 1 & 5 \\
\hline 41.A projection of future profits is provided & 4.50 & 9 & 2 & 5 \\
\hline 42.A projection of future sales is provided & 4.60 & 3 & 3 & 5 \\
\hline \multicolumn{5}{|l|}{ 5. Management discussion and analysis } \\
\hline 43.Change in sales & 4.30 & 22 & 3 & 5 \\
\hline 44.Change in operating income & 4.30 & 22 & 2 & 5 \\
\hline 45.Change in cost of goods sold & 4.18 & 32 & 2 & 5 \\
\hline $\begin{array}{l}\text { 46. Change in cost of goods sold as a } \\
\text { percentage of sales }\end{array}$ & 3.98 & 42 & 2 & 5 \\
\hline 47.Change in gross profits & 4.35 & 16 & 3 & 5 \\
\hline $\begin{array}{l}\text { 48. Change in gross profits as a percentage } \\
\text { of sales }\end{array}$ & 4.17 & 33 & 2 & 5 \\
\hline $\begin{array}{l}\text { 49.Change in selling and administrative } \\
\text { expenses }\end{array}$ & 3.85 & 55 & 2 & 5 \\
\hline $\begin{array}{l}\text { 50.Change in interest expense or interest } \\
\text { income }\end{array}$ & 4 & 39 & 2 & 5 \\
\hline 51.Change in net income & 4.55 & 5 & 2 & 5 \\
\hline 52.Change in inventory & 3.95 & 46 & 2 & 5 \\
\hline 53.Change in account receivable & 4.22 & 30 & 2 & 5 \\
\hline 54.Change in capital expenditures or R \& D & 3.88 & 50 & 2 & 5 \\
\hline 55.Change in market share & 4.45 & 13 & 3 & 5 \\
\hline \multicolumn{5}{|l|}{ 6. Information on the intangibles } \\
\hline 56.Description of key customers & 3.90 & 48 & 1 & 5 \\
\hline 57.Description of key suppliers & 3.87 & 51 & 2 & 5 \\
\hline 58.Description of the activities of $\mathrm{R} \& \mathrm{D}$ & 3.65 & 63 & 1 & 5 \\
\hline
\end{tabular}




\begin{tabular}{|c|c|c|c|c|}
\hline 59.Results of R \& D implemented & 3.78 & 59 & 2 & 5 \\
\hline \multicolumn{5}{|l|}{ 7. Social and environmental Information } \\
\hline $\begin{array}{l}\text { 60.Rate of employee } \\
\text { absenteeism and number of strike days }\end{array}$ & 3.13 & 67 & 1 & 5 \\
\hline $\begin{array}{lll}\text { 61.Training } & \text { and skills } & \text { development } \\
\text { for employees } & & \end{array}$ & 3.58 & 65 & 1 & 5 \\
\hline $\begin{array}{l}\text { 62.Description of } \\
\text { donations, grants, financial aid }\end{array}$ & 2.68 & 72 & 1 & 5 \\
\hline $\begin{array}{l}\text { 63.Description of the firm's commitment to } \\
\text { the community for specific social } \\
\text { projects(community activities, cultural, } \\
\text { educational, recreational and sports) }\end{array}$ & 2.68 & 72 & 1 & 5 \\
\hline $\begin{array}{l}\text { 64.Statement of activities for the protection } \\
\text { and preservation of the physical } \\
\text { environment(natural } \\
\text { conservation, energy } \\
\text { management, wildlife and flora ...) }\end{array}$ & 3.08 & 68 & 1 & 5 \\
\hline 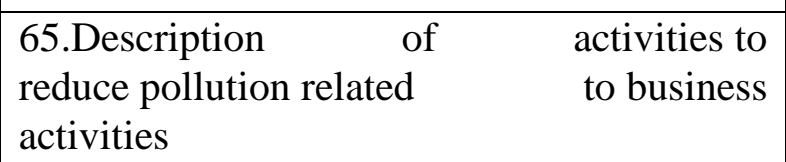 & 2.95 & 69 & 1 & 5 \\
\hline $\begin{array}{l}\text { 66.Production and promotion } \\
\text { of ecological products (prohibiting the use } \\
\text { of chemical components harmful to } \\
\text { health and ecosystems, recyclable packaging } \\
\text { design... }\end{array}$ & 2.85 & 70 & 1 & 5 \\
\hline
\end{tabular}

\section{Information on corporate governance}

\begin{tabular}{|l|c|c|c|c|}
\hline 67.Ownership structure (major shareholders) & 4.65 & 1 & 3 & 5 \\
\hline $\begin{array}{l}\text { 68.Percentage ownership by major } \\
\text { shareholders }\end{array}$ & 4.55 & 5 & 3 & 5 \\
\hline 69.Composition of the Board & 4.27 & 24 & 3 & 5 \\
\hline 70.The mandates of the administrators & 3.82 & 56 & 2 & 5 \\
\hline 71.Profile of administrators & 3.85 & 55 & 2 & 5 \\
\hline 72.The frequency of meetings of the Board & 3.55 & 66 & 1 & 5 \\
\hline
\end{tabular}

UPA $=\Sigma$ Points assigned by the respondents to the item / Number of respondents

The scope of voluntary information demand in the annual reports is reported in Table 3 . The UPA variable average is equal to 4.02; its maximum is 4.65 and its standard deviation 0.44 . In addition, the maximum weight for all the items is equal to 5 with 14 items having a weight varying between 3 and 5. It appears that very few items are perceived to be little useful while 
most of them are perceived to be very useful.

On the one hand, the most useful items are: "Ownership structure", "A projection of future sales is provided" and "Market share". On the other hand, the perceived utilities are low for the items on societal information. The smallest value of the UPA variable for these items is equal to 2.68 and the average is 2.99 . This could be explained by the fact that the concept of "corporate citizenship" is not yet well developed among the analysts.

For the sub index of voluntary information closely linked to the mandatory one, the UPA variable average is equal to 4.10 , its maximum is 4.65 and its minimum is 2.68 . This means that analysts think that voluntary information closely linked to the mandatory one is useful. For the sub index of voluntary information not closely linked to the mandatory one, the UPA variable average is equal to 3.98 , its maximum is 4.60 and its minimum is 2.68 . These results make us conclude that the analysts consider voluntary information not closely linked to the mandatory one less useful than the closely linked one. Moreover, we notice that eight items with prospective orientation are very useful but considered voluntary and not closely linked to the mandatory information. This means that the Tunisian regulations on the informational content of the management reports do not adequately meet the information needs of the analysts.

We mention that institutional factors such as investor protection laws, corporate governance structures, and the quality of law enforcement jointly influence the demand for accounting information (Kothari, 2000).

4.1.2 Scope of the voluntary information supply in the annual reports

Table 4. Supply of voluntary information in annual reports

\begin{tabular}{|l|c|c|c|c|}
\hline \multicolumn{1}{|c|}{ Items } & $\begin{array}{c}\text { Number of } \\
\text { the firms } \\
\text { likely to } \\
\text { disclose the } \\
\text { item }\end{array}$ & $\begin{array}{c}\text { Average } \\
\text { disclosure } \\
\text { score }\end{array}$ & $\begin{array}{c}\text { Number of } \\
\text { the firms } \\
\text { disclosing } \\
\text { the item }\end{array}$ & $\begin{array}{c}\text { Percentage } \\
\text { of the firms } \\
\text { disclosing } \\
\text { the item }\end{array}$ \\
\hline \begin{tabular}{l} 
1. Background Information \\
\hline $\begin{array}{l}\text { 1.A statement of corporate goals or } \\
\text { objectives is provided }\end{array}$
\end{tabular}$\quad 24$ & 2.8 & 21 & 87.5 \\
\hline $\begin{array}{l}\text { 2.A general statement of corporate } \\
\text { strategy is provided }\end{array}$ & 24 & 3.47 & 21 & 87.5 \\
\hline $\begin{array}{l}\text { 3.Actions taken during the year to } \\
\text { achieve the corporate goals are } \\
\text { discussed }\end{array}$ & 24 & 3.72 & 21 & 87.5 \\
\hline $\begin{array}{l}\text { 4.Planned actions to be taken in future } \\
\text { years are discussed }\end{array}$ & 24 & 2.89 & 18 & 75 \\
\hline $\begin{array}{l}\text { 5.A time frame for achieving corporate } \\
\text { goals is defined }\end{array}$ & 24 & 1.59 & 10 & 41.67 \\
\hline
\end{tabular}




\begin{tabular}{|c|c|c|c|c|}
\hline 6.Barriers to entry are discussed & 22 & 1.99 & 14 & 63.64 \\
\hline $\begin{array}{l}\text { 7.Impact of barriers to entry on current } \\
\text { profits are discussed }\end{array}$ & 22 & 1.05 & 7 & 31.82 \\
\hline $\begin{array}{l}\text { 8. The competitive environment is } \\
\text { discussed }\end{array}$ & 21 & 1.62 & 9 & 42.86 \\
\hline $\begin{array}{l}\text { 9.The impact of competition on current } \\
\text { profits is discussed }\end{array}$ & 21 & 0.21 & 2 & 9.52 \\
\hline $\begin{array}{l}\text { 10.The impact of competition on future } \\
\text { profits is discussed }\end{array}$ & 21 & 0.2 & 1 & 4.76 \\
\hline $\begin{array}{l}\text { 11.A general description of the } \\
\text { business is provided }\end{array}$ & 24 & 3.64 & 23 & 95.83 \\
\hline $\begin{array}{l}\text { 12.The principal products produced are } \\
\text { identified }\end{array}$ & 24 & 3.57 & 22 & 91.67 \\
\hline $\begin{array}{l}\text { 13.Specific characteristics of these } \\
\text { products are described }\end{array}$ & 24 & 2.73 & 18 & 75 \\
\hline 14.The principal markets are identified & 20 & 3.44 & 17 & 85 \\
\hline $\begin{array}{l}\text { 15.Specific characteristics of these } \\
\text { markets are described }\end{array}$ & 20 & 2.68 & 14 & 70 \\
\hline \multicolumn{5}{|l|}{ 2. Summary of historical results } \\
\hline 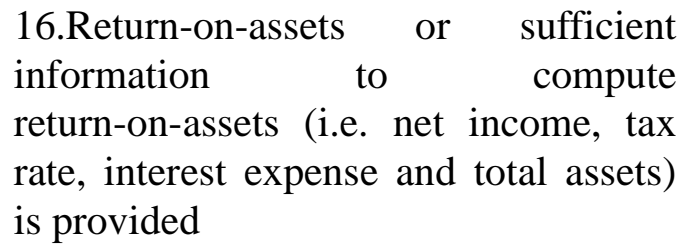 & 24 & 1.8 & 10 & 41.67 \\
\hline $\begin{array}{l}\text { 17. Net profit margin or sufficient } \\
\text { information to compute net profit } \\
\text { margin (i.e. net income, tax rate, } \\
\text { interest expense and sales) is provided }\end{array}$ & 24 & 3.96 & 22 & 91.67 \\
\hline $\begin{array}{l}\text { 18.Asset turnover or sufficient } \\
\text { information to compute asset turnover } \\
\text { (i.e. sales and total assets) is provided }\end{array}$ & 24 & 1.65 & 10 & 41.67 \\
\hline $\begin{array}{l}\text { 19.Return-on-equity or sufficient } \\
\text { information to compute } \\
\text { return-on-equity (i.e. net income and } \\
\text { stockholders equity) is provided }\end{array}$ & 24 & 3.16 & 18 & 75 \\
\hline $\begin{array}{l}\text { 20.A summary of sales and net income } \\
\text { for at least the most recent eight } \\
\text { quarter is provided }\end{array}$ & 24 & $\underline{4.22}$ & 24 & 100 \\
\hline \multicolumn{5}{|l|}{ 3. Key non-financial statistics } \\
\hline 21.Number of employees & 24 & 2.09 & 14 & 58.33 \\
\hline
\end{tabular}




\begin{tabular}{|c|c|c|c|c|}
\hline 22.Order backlog & 18 & 1.09 & 5 & 27.78 \\
\hline $\begin{array}{l}\text { 23.Percentage of order backlog to be } \\
\text { shipped next year }\end{array}$ & 18 & 0.24 & 1 & 5.56 \\
\hline $\begin{array}{l}\text { 24.Percentage of sales in products } \\
\text { designed in the last five years }\end{array}$ & 13 & 0.61 & 2 & 15.38 \\
\hline 25.Market share & 17 & 2.44 & 9 & 52.94 \\
\hline $\begin{array}{l}\text { 26.Amount of new orders placed this } \\
\text { year }\end{array}$ & 18 & 0.69 & 3 & 16.67 \\
\hline 27.Units sold & 18 & 2.05 & 9 & 50 \\
\hline 28.Unit selling price & 17 & 2 & 9 & 52.94 \\
\hline 29.Growth in units sold & 18 & 2.27 & 10 & 55.56 \\
\hline 30.Production lead time & 15 & 0.49 & 2 & 13.33 \\
\hline $\begin{array}{l}\text { 31.Sales growth in key regions not } \\
\text { reported as geographic segments }\end{array}$ & 21 & 2.2 & 12 & 57.14 \\
\hline 32.Volume of materials consumed & 21 & 0.88 & 5 & 23.81 \\
\hline 33.Price of materials consumed & 20 & 1.98 & 10 & 50 \\
\hline $\begin{array}{l}\text { 34.Growth in sales of key products not } \\
\text { reported as product segments }\end{array}$ & 22 & 3.08 & 17 & 77.27 \\
\hline \multicolumn{5}{|l|}{ 4. Projected information } \\
\hline $\begin{array}{l}\text { 35.A comparison of previous earnings } \\
\text { projections to actual earnings is } \\
\text { provided }\end{array}$ & 24 & 0.74 & 4 & 16.67 \\
\hline $\begin{array}{c}\text { 36.A comparison of previous sales } \\
\text { projections to actual sales is provided }\end{array}$ & 24 & 1.02 & 6 & 25 \\
\hline $\begin{array}{l}\text { 37.The impact of opportunities } \\
\text { available to the firm on future sales or } \\
\text { profits }\end{array}$ & 24 & 1.93 & 12 & 50 \\
\hline $\begin{array}{l}\text { 38. The impact of risks facing the firm } \\
\text { on future sales or profits is discussed }\end{array}$ & 24 & 2.67 & 17 & 70.83 \\
\hline $\begin{array}{l}\text { 39.A forecast of market share is } \\
\text { provided }\end{array}$ & 20 & 0.65 & 3 & 15 \\
\hline 40.A cash flow projection is provided & 24 & 0.09 & 1 & 4.17 \\
\hline $\begin{array}{l}\text { 41.A projection of future profits is } \\
\text { provided }\end{array}$ & 24 & 0.84 & 5 & 20.83 \\
\hline $\begin{array}{l}\text { 42.A projection of future sales is } \\
\text { provided }\end{array}$ & 24 & 2.11 & 11 & 45.83 \\
\hline
\end{tabular}




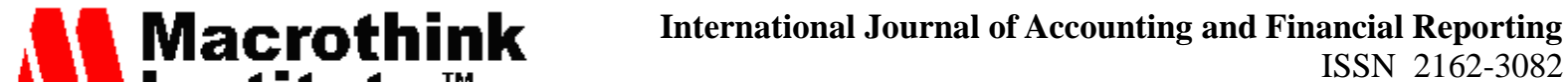 2012, Vol. 2, No. 2}

\begin{tabular}{|c|c|c|c|c|}
\hline \multicolumn{5}{|c|}{ 5. Management discussion and analysis } \\
\hline 43.Change in sales & 24 & $\underline{4.3}$ & 24 & 100 \\
\hline 44.Change in operating income & 24 & 3.4 & 19 & 79.17 \\
\hline 45.Change in cost of goods sold & 22 & 1.52 & 9 & 40.91 \\
\hline $\begin{array}{l}\text { 46.Change in cost of goods sold as a } \\
\text { percentage of sales }\end{array}$ & 22 & 0.18 & 1 & 4.55 \\
\hline 47.Change in gross profits & 23 & 1.89 & 10 & 43.48 \\
\hline $\begin{array}{l}\text { 48.Change in gross profits as a } \\
\text { percentage of sales }\end{array}$ & 23 & 0.18 & 1 & 4.35 \\
\hline $\begin{array}{l}\text { 49.Change in selling and } \\
\text { administrative expenses }\end{array}$ & 23 & 0.33 & 2 & 8.7 \\
\hline $\begin{array}{l}\text { 50.Change in interest expense or } \\
\text { interest income }\end{array}$ & 24 & 1.5 & 9 & 37.5 \\
\hline 51.Change in net income & 24 & $\underline{4.17}$ & 22 & 91.67 \\
\hline 52.Change in inventory & 21 & 2.07 & 11 & 52.38 \\
\hline 53.Change in account receivable & 24 & 1.06 & 6 & 25 \\
\hline $\begin{array}{l}\text { 54.Change in capital expenditures or } \mathrm{R} \\
\text { \& D }\end{array}$ & 17 & 0.23 & 1 & 5.88 \\
\hline 55.Change in market share & 19 & 0.92 & 4 & 21.05 \\
\hline \multicolumn{5}{|l|}{ 6. Information on the intangibles } \\
\hline 56.Description of key customers & 20 & 1.85 & 11 & 55 \\
\hline 57.Description of key suppliers & 17 & 0.57 & 4 & 23.53 \\
\hline $\begin{array}{l}\text { 58.Description } \\
\text { activities of } R \text { \& D }\end{array} \quad$ of $\quad$ the & 17 & 1.83 & 10 & 58.82 \\
\hline 59.Results of R \& D implemented & 17 & 1.89 & 9 & 52.94 \\
\hline \multicolumn{5}{|c|}{ 7. Social and environmental Information } \\
\hline $\begin{array}{l}\text { 60.Rate of } \\
\text { absenteeism and number of strike days }\end{array}$ & 23 & 0.41 & 3 & 13.04 \\
\hline $\begin{array}{l}\text { 61.Training and skills development } \\
\text { for employees }\end{array}$ & 23 & 1.32 & 9 & 39.13 \\
\hline $\begin{array}{l}\text { 62.Description of charitable } \\
\text { donations, grants, financial aid }\end{array}$ & 23 & 0.47 & 5 & 21.74 \\
\hline $\begin{array}{lr}63 . \text { Description of the } & \text { firm's } \\
\text { commitment to } & \text { the }\end{array}$ & 22 & 0.24 & 3 & 13.64 \\
\hline
\end{tabular}


community for specific social projects(community activities, cultural, educational, recreational and sports)

64.Statement of activities for the protection and preservation of the physical environment(natural resources conservation, energy management, wildlife and flora ...)

65.Description of activities to reduce pollution related to business activities

66.Production and promotion
of ecological products (prohibiting the use of chemical components harmful to health and ecosystems, recyclable packaging design...

\section{Information on corporate governance}

\begin{tabular}{|l|c|c|c|c|}
\hline $\begin{array}{l}\text { 67.Ownership structure (major } \\
\text { shareholders) }\end{array}$ & 24 & 2.13 & 11 & 45.83 \\
\hline $\begin{array}{l}\text { 68.Percentage ownership by major } \\
\text { shareholders }\end{array}$ & 24 & 1.9 & 10 & 41.67 \\
\hline 69.Composition of the Board & 24 & 2.85 & 16 & 66.67 \\
\hline 70.The mandates of the administrators & 24 & 0.8 & 5 & 20.83 \\
\hline $\begin{array}{l}\text { 71.Profile of administrators } \\
\text { 72.The frequency of meetings of the } \\
\text { Board }\end{array}$ & 24 & 0.3 & 2 & 12.5 \\
\hline
\end{tabular}

Average disclosure score $=\Sigma$ Points assigned to the item according to the annual reports coding / Number of the companies likely to disclose the item

The scope of voluntary information supply in the annual reports is reported in Table 4. The mean variable of the "Average disclosure score" is equal to 1.72, its maximum is 4.3 and the minimum is 0.09 . The standard deviation of this variable is equal to 1.17 and when we compare it with its average; we find that there is a great variability in the disclosure of the various studied items. In other words, some items are better disclosed than others. Moreover, we notice that the rate of firms that disclose the various items of the grid is highly variable (it varies between $4.17 \%$ and $100 \%$ ).

On the one hand, only three items have average disclosure scores that vary between 4 and 4.3. It seems that very few items are considered adequately disclosed. On the other hand, 26 items have an average disclosure score below 1 . These results help us conclude that a significant proportion of the items $(36.11 \%)$ is not properly disclosed. 
For the sub index of voluntary information closely linked to the mandatory one, the mean of the variable "Average disclosure score" is equal to 2.66, its maximum is 4.30 and its minimum is 0.47 . Moreover, the average rate of companies that disclose the items of this sub index rises to $66.86 \%$. What is striking is that the three items that have the highest disclosure scores.(greater than 4): "A summary of sales and net income for at least the most recent eight quarter is provided", " Changes in sales" and " Changes in net income " are included in this sub index. These results help us state that voluntary information closely linked to the mandatory one tends to be adequately disclosed.

For the sub index of voluntary information not closely linked to the mandatory one, the mean of the variable "Average disclosure score" is equal to 1.27, its maximum is 3.72 and its minimum is 0.09 . Moreover, the average rate of the companies that disclose the items of this sub index is $34.60 \%$. We notice that 22 items in this sub index have an average disclosure score inferior to 1 (representing $44.89 \%$ of the total items of this sub index). These results make us conclude that the disclosure of voluntary information not closely linked to the mandatory one is quite negligible and that this type of information is much less disclosed than the voluntary information closely linked to the mandatory one.

\subsection{Convergences and divergences between the information supply and demand in the annual reports}

Table 5 presents the DDS variable and the classification of the items according to this variable. The figures of this table help us determine the divergences and convergences between demand and supply of voluntary information in annual reports.

Table 5. Demand and Supply of voluntary information in annual reports

\begin{tabular}{|l|c|c|}
\hline \multicolumn{1}{|c|}{ Items } & DDS & $\begin{array}{c}\text { Classification } \\
\text { according to } \\
\text { the DDS }\end{array}$ \\
\hline \multicolumn{1}{|c|}{ 1. Background Information } & 64.58 & 17 \\
\hline 1.A statement of corporate goals or objectives is provided & 77.08 & 11 \\
\hline 2.A general statement of corporate strategy is provided & 87.5 & 7 \\
\hline $\begin{array}{l}\text { 3.Actions taken during the year to achieve the corporate goals } \\
\text { are discussed }\end{array}$ & 64.58 & 16 \\
\hline 4.Planned actions to be taken in future years are discussed & 37.5 & 39 \\
\hline 5.A time frame for achieving corporate goals is defined & 52.27 & 25 \\
\hline 6.Barriers to entry are discussed & 27.27 & 45 \\
\hline 7.Impact of barriers to entry on current profits are discussed & 35.71 & 43 \\
\hline 8.The competitive environment is discussed & 4.76 & 68 \\
\hline 9.The impact of competition on current profits is discussed & 4.5 & 70 \\
\hline 10.The impact of competition on future profits is discussed & 93.75 & 3 \\
\hline 11.A general description of the business is provided & & \\
\hline
\end{tabular}




\section{Macrothink}

International Journal of Accounting and Financial Reporting

ISSN 2162-3082

2012, Vol. 2, No. 2

\begin{tabular}{|c|c|c|}
\hline 12.The principal products produced are identified & 89.58 & 6 \\
\hline 13.Specific characteristics of these products are described & 72.92 & 13 \\
\hline 14.The principal markets are identified & 80 & 8 \\
\hline 15.Specific characteristics of these markets are described & 65 & 15 \\
\hline \multicolumn{3}{|l|}{ 2. Summary of historical results } \\
\hline $\begin{array}{l}\text { 16.Return-on-assets or sufficient information to compute } \\
\text { return-on-assets (i.e. net income, tax rate, interest expense and } \\
\text { total assets) is provided }\end{array}$ & 41.67 & 37 \\
\hline $\begin{array}{l}\text { 17. Net profit margin or sufficient information to compute net } \\
\text { profit margin (i.e. net income, tax rate, interest expense and } \\
\text { sales) is provided }\end{array}$ & 91.67 & 4 \\
\hline $\begin{array}{l}\text { 18. Asset turnover or sufficient information to compute asset } \\
\text { turnover (i.e. sales and total assets) is provided }\end{array}$ & 41.67 & 37 \\
\hline $\begin{array}{l}\text { 19.Return-on-equity or sufficient information to compute } \\
\text { return-on-equity (i.e. net income and stockholders equity) is } \\
\text { provided }\end{array}$ & 75 & 12 \\
\hline $\begin{array}{l}\text { 20.A summary of sales and net income for at least the most } \\
\text { recent eight quarter is provided }\end{array}$ & 100 & 1 \\
\hline \multicolumn{3}{|l|}{ 3. Key non-financial statistics } \\
\hline 21.Number of employees & 58.33 & 19 \\
\hline 22.Order backlog & 27.78 & 44 \\
\hline 23.Percentage of order backlog to be shipped next year & 5.56 & 67 \\
\hline $\begin{array}{l}\text { 24.Percentage of sales in products designed in the last five } \\
\text { years }\end{array}$ & 15.38 & 57 \\
\hline 25.Market share & 52.94 & 23 \\
\hline 26.Amount of new orders placed this year & 16.67 & 55 \\
\hline 27.Units sold & 50 & 28 \\
\hline 28.Unit selling price & 52.94 & 22 \\
\hline 29.Growth in units sold & 55.56 & 21 \\
\hline 30.Production lead time & 13.33 & 60 \\
\hline $\begin{array}{l}\text { 31.Sales growth in key regions not reported as geographic } \\
\text { segments }\end{array}$ & 57.14 & 20 \\
\hline 32. Volume of materials consumed & 23.81 & 48 \\
\hline 33.Price of materials consumed & 50 & 28 \\
\hline $\begin{array}{l}\text { 34.Growth in sales of key products not reported as product } \\
\text { segments }\end{array}$ & 77.27 & 10 \\
\hline \multicolumn{3}{|l|}{ 4. Projected information } \\
\hline 35.A comparison of previous earnings projections to actual & 16.67 & 55 \\
\hline
\end{tabular}


earnings is provided

36.A comparison of previous sales projections to actual sales is provided

37.The impact of opportunities available to the firm on future sales or profits

38.The impact of risks facing the firm on future sales or profits is discussed

39.A forecast of market share is provided 40.A cash flow projection is provided

41.A projection of future profits is provided

42.A projection of future sales is provided

\begin{tabular}{|c|c|}
\hline 22.91 & 49 \\
\hline 45.83 & 32 \\
\hline 62.5 & 18 \\
\hline 15 & 58 \\
\hline 2.08 & 72 \\
\hline 18.75 & 53 \\
\hline 45.83 & 31 \\
\hline
\end{tabular}

\section{Management discussion and analysis}

43. Change in sales

44. Change in operating income

45.Change in cost of goods sold

46.Change in cost of goods sold as a percentage of sales

47. Change in gross profits

48.Change in gross profits as a percentage of sales

49. Change in selling and administrative expenses

50. Change in interest expense or interest income

51.Change in net income

52. Change in inventory

53. Change in account receivable

54.Change in capital expenditures or R \& D

55.Change in market share

\begin{tabular}{|c|c|}
\hline 100 & 1 \\
\hline 79.17 & 9 \\
\hline 36.36 & 42 \\
\hline 4.55 & 69 \\
\hline 43.48 & 35 \\
\hline 4.35 & 71 \\
\hline 8.7 & 64 \\
\hline 37.5 & 39 \\
\hline 91.67 & 4 \\
\hline 52.38 & 24 \\
\hline 25 & 47 \\
\hline 5.88 & 66 \\
\hline 20.7 & 51 \\
\hline
\end{tabular}

\section{Information on the intangibles}

56.Description of key customers

57.Description of key suppliers

58.Description of the activities of $\mathrm{R} \& \mathrm{D}$

59.Results of R \& D implemented

\begin{tabular}{|c|c|}
\hline 47.5 & 30 \\
\hline 14.71 & 59 \\
\hline 50.01 & 26 \\
\hline 50 & 27 \\
\hline
\end{tabular}

\section{Social and environmental Information}

60.Rate of employee absenteeism and number of strike days

61.Training and skills development for employees

62.Description of charitable donations, grants, financial aid

63.Description of the firm's commitment to the community for specific social projects(community activities, cultural, educational, recreational and sports)

\begin{tabular}{|l|l|l|}
\hline 13.04 & 61 \\
\hline & 36.96 & 41 \\
\hline 17.39 & 54 \\
\hline & 9.09 & 63 \\
\hline
\end{tabular}




\section{Ml Macrothink}

International Journal of Accounting and Financial Reporting

ISSN 2162-3082

2012, Vol. 2, No. 2

\begin{tabular}{|l|c|c|}
\hline \multicolumn{2}{|l|}{$\begin{array}{l}\text { 64.Statement of activities for the protection and preservation of } \\
\text { the physical environment(natural resources } \\
\text { conservation, energy management, wildlife and flora ...) }\end{array}$} & 44.74 \\
\hline $\begin{array}{l}\text { 65.Description of activities to reduce pollution related } \\
\text { to business activities }\end{array}$ & 26.48 & 46 \\
\hline $\begin{array}{l}\text { 66.Production and } \\
\text { of ecological products (prohibiting the use promotion } \\
\text { components harmful to } \\
\text { ecosystems, recyclable packaging design... }\end{array} \quad$ health and \\
\hline
\end{tabular}

\section{Information on corporate governance}

\begin{tabular}{|l|c|c|}
\hline 67.Ownership structure (major shareholders) & 45.83 & 32 \\
\hline 68.Percentage ownership by major shareholders & 41.67 & 36 \\
\hline 69.Composition of the Board & 66.67 & 14 \\
\hline 70.The mandates of the administrators & 20.83 & 50 \\
\hline 71.Profile of administrators & 12.5 & 62 \\
\hline 72.The frequency of meetings of the Board & 8.33 & 65 \\
\hline \multicolumn{2}{|c|}{ DDS = (Average disclosure score of the item / UPA of the item)*100 } \\
\hline
\end{tabular}

4.2.1 Divergences between the voluntary information supply and demand in the annual reports

By comparing the values of the "Average disclosure score" with the UPA values, on the one hand, and the ranking of the items according to their UPA with their ranks according to their DDS, on the other hand, we notice a large inadequacy between supply and demand for 29 items (their DDS are below 30\%). We can say that only two items are considered to be voluntary and closely linked to the mandatory disclosure (No. 62 and No. 70), while twentyseven items are considered to be voluntary and not closely linked to the mandatory disclosure (No. 7, No. 9, No. 10, No. 22, No. 23, No. 24, No. 26, No. 30, No. 32, No. 35, No. 36, No. 39, No. 40, No. 41, No. 46, No. 48, No. 49, No. 53, No. 54, No. 55, No. 57, No. 60, No. 63, No. 65, No. 66, No. 71 and No. 72). What draws our attention is the total inadequacy between supply and demand for the items: No. 10, No. 40, No. 46 and No. 48.

When looking at the DDS, we notice that the extent of the voluntary information supply compared to its demand is weak for most of the items. Indeed, the DDS are below $50 \%$ for 40 items (which corresponds to $55.55 \%$ of the items). This discrepancy between supply and demand of voluntary information is due to the fact that several items are not properly disclosed although they are useful for the analysts. In other words, the 'laissez-faire' could not reach an optimal level of disclosure.

Different explanations could be mobilized for the discrepancy observed between supply and demand for voluntary information (Khlifi and Bouri, 2010): the agency theory, the property cost theory, the lack of information within the company and the misconception of the information needs of the external users of the annual reports. 


\section{MInstitute Mach $^{m}$}

International Journal of Accounting and Financial Reporting

ISSN 2162-3082

2012, Vol. 2, No. 2

First, this discrepancy might be desired by companies for the purpose of maintaining their information asymmetry advantage. This information asymmetry enables the manager to use voluntary information for his own interest, but this act should not be questionable either by the shareholders or by a third party. By referring to the agency theory, we can say that there is an information asymmetry between the shareholders and the managers due to the separation of ownership and management (Jensen and Meckling, 1976). In the Tunisian context, agency problems (mainly type II) exist between the supervising shareholders (insiders) and the minority ones (outsiders). In this situation, the "insiders" are expected to act as opportunistic agents encouraged to maximize their interests at the expense of the "outsiders".

Secondly, voluntary disclosure generates direct and indirect costs for the businesses. It is likely that the items useful for the analysts and which are virtually absent in the annual management reports could be exploited by the competitors against the company that discloses. The studies of (Prencipe, 2004; Clinch and Verrecchia, 1997; Wagenhofer, 1990; Darrough and Soughton, 1990), confirm that fall of the disclosure level is mainly due to the loss of the company's competitive advantage. Generally, companies avoid disclosing information that causes the rise of the property cost (or that may affect the possessor of the information). These costs arise when a party whose interests are not compatible with those of the company uses disclosed information against the interests of that company. It is therefore difficult to require the disclosure of certain information needed by the analysts which could be used by the competitors at the expense of the company. Beside the fear of losing a competitive advantage, voluntary disclosure generates direct costs such as opportunity costs that are difficult to quantify (for example: the managerial time).

Thirdly, sometimes the company does not disclose because the information is not available even for its internal management purposes. Indeed, few Tunisian companies have a satisfactory information system.

Fourthly, the gap between supply and demand for voluntary information is likely to be the result of a misunderstanding of the analysts' information needs. In this way, the results in the study of (Yaftian and Mirshekary, 2005) reveal that the primary factor behind the low level of disclosure in the annual reports of a sample of Iranian companies is that the business leaders don't know the external users' needs for information.

4.2.2 Convergences between the voluntary information supply and demand in the annual reports

We can say that there is no huge gap between information supply and demand for 9 items (representing $12.50 \%$ of the items). These items are disclosed by companies in a partially adequate way compared to their utility for the analysts. They have a fairly good disclosure extent as their DDS and the rate of the companies which disclose them is above $79 \%$. Moreover, their "Average disclosure scores" are very close to their UPA. It should be pointed out that only one single item is said to be voluntary and not closely linked to the mandatory disclosure (No. 3), while the remaining eight items are considered voluntary and closely linked to the mandatory disclosure (No. 11, No. 12 , No. 14, No. 17, No. 20, No. 43, No. 44 and No. 51). This result could be explained by the analysts' belief that the Tunisian firms' 
accounting system (1997) has succeeded in improving the information content of the regulated accounting filings and by then their decision making.

We notice that the items subject to a certain convergence between supply and demand are not highly confidential information for businesses and regarded as items with voluntary disclosure closely linked to the mandatory one. For example, when we make a simple calculation (and / or) a comment using the numbers which are already in the financial statements that the disclosure is mandatory (items No. 17, No. 20, No. 43, No. 44 and No. 51), and so is the case of items No. 11 and No. 12 which are in principle well known by the users of the annual reports. It should be pointed out that four items out of the 9 mentioned above are included in the "Background Information" category.

Different explanations could be given about the observed partial convergence between supply and demand for voluntary information (Khlifi and Bouri, 2010): the perspective of free market, the theories of signals and of legitimacy.

First, in the perspective of free market of voluntary disclosure, it is the market forces which identify the extent of such disclosure. In other words, it is the supply and demand rule which prevails. This situation differs from that of the regulated economy in which the standard setter distorts the market signals by directly or indirectly regulating the information to be disclosed.

Second, the managers may disclose to the financial market to reduce the information asymmetry. Indeed, increasing the range of voluntary disclosure is an implicit contract by which the leaders reassure the shareholders who manage the business appropriately. The signal theory is based on the idea that information is not shared by all at the same time and that information asymmetry is the rule (Spence, 1973). In this context, the leaders consider voluntary information a deliberate signal to the financial market in order to distinguish their businesses from other businesses in the financial market. This signal helps investors better assess the prospects for the company's future profitability and reduce the uncertainty of its cash flows the thing which could improve their investment decisions.

Third, relying on the legitimacy theory, a company is motivated to practice voluntary disclosure to gain its legitimacy (DiMaggio and Powell, 1983). This theory postulates that firms shall ensure that their actions meet the needs of the environment in which they operate. These needs are built from norms, values and social beliefs. Therefore, voluntary disclosure, depending on the socially constructed system, represents a strengthening means of the company's legitimacy.

\subsection{Summary of the empirical results}

Like (Ho and Wong, 2004), we note that very few items are disclosed under the analysts' expectations. Several items have a higher UPA but are not disclosed by the majority of the companies likely to disclose. Moreover, there are items that virtually don't figure in the annual management reports despite their great usefulness to analysts. In addition, we found that the overall degree of voluntary disclosure amounts to $43.14 \%$ indicating a mismatch between supply and demand for voluntary information. It should be noted that Buzby (1974) found an overall degree of disclosure of around $51.2 \%$. 


\section{MInstitute Macrothink $_{\text {Int }}$}

International Journal of Accounting and Financial Reporting

ISSN 2162-3082

2012, Vol. 2, No. 2

Moreover, the Spearman correlation coefficient between the two rankings (according to the DDS and the UPA) is equal to 0.202 and statistically significant at $10 \%$ ( $\operatorname{sig}=0.088$ ). The results of the correlation test are shown in Appendix 2. The very low coefficient value strengthens the previous findings. It indicates that the ranking of the items according to their DDS is not very correlated with the one based on their UPA. Similarly, (Chow and Wong-Boren, 1987) claim that the number of firms disclosing the items is not significantly correlated with the importance attached by the users of annual reports to these items (the bankers responsible for allocating credits). They find that the Pearson and Spearman correlations between these two variables are respectively 0.086 and 0.122 . Furthermore, we notice that the societal dimension of the sustainable development is considered neither useful for the analysts nor widely disclosed by the companies.

These findings enable us to confirm our hypothesis which states that the amount of voluntary information is not disclosed in accordance with the analysts' needs. Like Graham et al., (2005), we could confirm that the voluntary supply of information is a set of contradictory forces (incentive and deterrent forces). Indeed, the process of voluntary disclosure results from a tradeoff between the advantages and the disadvantages of such disclosure (Beyer et al., 2009). Our results imply that the free market forces of voluntary information (supply and demand) cannot help guarantee an optimal voluntary disclosure.

\section{Conclusion}

The emergence of many changes connected to the (SEST) informational environment has underlined the current strategic role of voluntary disclosure in the annual reports. Voluntary disclosure, which used to have a minor role in the company's external reports, is now actively involved in the process of the decision making by the external users of the annual reports. However, this development created new users' expectations. Given the two-dimensional nature of the voluntary disclosure phenomenon, this research focuses on the analysis of the supply and demand in a financial marketing logic. More specifically, this research aims to determine the satisfaction degree of the external users' needs of the annual reports for voluntary information in Tunisia.

According to some analyzes, the results largely tend to confirm the hypothesis of the research. From the supply side, very few items are perceived to be of little use while most of them are perceived very useful. In addition, analysts believe that voluntary information not closely linked to the mandatory one is less useful than the one closely linked. On the demand side, a large proportion of items are not properly disclosed. In addition, voluntary disclosure of information not closely linked to the mandatory information is quite small and this type of information is much less disclosed than the voluntary information closely linked to the mandatory one. Moreover, the results show that the extent of the corporate voluntary information disclosure is relatively low compared to the analysts' demand. One the one hand, most of the items for which supply and demand converge, are items with voluntary disclosure closely linked to the mandatory one. Besides, these items are considered to be slightly more useful and much better disclosed by the companies than the ones not closely linked to the mandatory disclosure. On the other hand, most of the items for which supply and demand 
diverge, are the latter ones.

This research contributes to the literature on financial transparency and voluntary disclosure in the emerging markets. We can say that the overall results of this research have practical implications. We find that very few items are considered adequately disclosed and that the disclosure of voluntary information not closely linked to the mandatory one is quite negligible. These results imply that the Tunisian listed companies should improve the disclosure of voluntary items and mainly the disclosure of voluntary information not closely linked to the mandatory one. More specifically, these companies should disclose the most useful items for the external users of the annual reports, like: «Ownership structure », «A projection of future sales is provided» and « Market share ». This implies that the identification of the information necessary for financial analysts will help the business leaders redefine their responsibilities regarding disclosure. Indeed, voluntary disclosure could be crafted in response to the needs of the external users of the annual reports through the disclosure of information needed by such users. Moreover we find a large inadequacy between supply and demand of the voluntary information for: "The impact of competition on future profits is discussed», «A cash flow projection is provided», « Change in cost of goods sold as a percentage of sales » and «Change in gross profits as a percentage of sales ». This result implies that the companies should seek to disclose these items. This research raises the awareness of the Tunisian managers to pay attention to their voluntary disclosure in the annual reports to meet the growing needs of their external users. To conclude, this research encourages Tunisian managers to establish a system of effective corporate governance which protects the minority shareholders through a better disclosure in the management annual report to get the confidence of the stakeholders.

Like any research effort, our work suffers from a number of deficiencies among which the small size of the sample, the manual analysis of the content of the annual management reports and the focus on a single category of the users of these reports, namely the financial analysts and the portfolio managers.

This research provides some lines of thought that should be explored further. Our research can only help the launch of a debate on transparency, disclosure and the improvement of the quality of the external reporting, the key factors of the financial market functioning. Other qualitative studies, mainly the ones having an experimental nature, could be carried out about the investment decision making on the basis of the mandatory and voluntary information.

\section{Acknowledgement}

The author would like to thank her Ph.D supervisor Professor Hamadi MATOUSSI for his contribution and his valuable comments.

\section{References}

Act $\mathrm{n}^{\circ}$ 2005-96 (the October 18, 2005) on the strengthening of the financial security

Act $\mathrm{n}^{\circ}$ 1996-112 (the December 30,1996) on the Tunisian firms' accounting system

Al-Razeen, A. and Karbhari, Y. (2007), Interaction between compulsory and voluntary 


\section{Macrothink}

International Journal of Accounting and Financial Reporting ISSN 2162-3082 2012, Vol. 2, No. 2

disclosure in Saudi Arabian corporate annual reports, Managerial Auditing Journal, 19(3), $351-360$

Ball R., Kothari S.P. and Robin A. (2000), The effect of international institutional factors on properties of accounting earnings, Journal of Accounting and Economics, 29(1), 1-51

Barako, D. G. Hancock, P. and Izan, H. Y. (2006), Factors influencing voluntary corporate disclosure by Kenyan companies, Corporate Governance: An International Review, 14(2), 107-125

Beyer, A. Cohen, D. A. Lys, T. Z. and Walther, B. R. (2009), The financial reporting environment review of the recent literature, working paper: 2009 Journal of accounting and economics conference papers, Stanford University

Botosan, C. A. (1997), Disclosure level and the cost of equity capital, The Accounting Review, 72(3), 323-350

Buzby, S. L. (1974), Selected items of information and their disclosure in annual reports, The Accounting Review, 49(3), 423-435

Chow, C. W. and Wong-Boren, A. (1987), Voluntary financial disclosure by Mexican corporations, The accounting review, 62(3), 533-541

Clarkson, P. M., Kao, J. L. and Richardson, G. D. (1999), Evidence that management discussion and analysis (MD\&A) is a part of a firm's overall disclosure package, Contemporary Accounting Research, 16(1), 111-134

Clinch, G. and Verrecchia, R. E. (1997), Competitive disadvantage and discretionary disclosure in industries, Australian journal of management, 22(2), 125-138

Courtis, J. K. (1992), The reliability of perception-based annual report disclosure studies, Accounting and Business Research, 23(89), 31-43

Darrough, M. and Soughton, N. (1990), Financial disclosure policy in an entry game, Journal of Accounting and Economics, 12, 219-243

Depoers, F. (1998), L'offre volontaire d'information dans les rapports annuels des sociétés cotées: le cas français, Revue française de comptabilité, (305), 69-75

Depoers, F. (2000), L'offre volontaire d'information des sociétés cotées : concept et mesure, Comptabilité- Contrôle-Audit, 6(2), 115-131

Di Maggio, P. J. and Powell, W. W. (1983), The iron cage revisited: institutional isomorphism and collective rationality in organizational fields, American Sociological review, 48, 60-147

Graham, J. R., Harvey, C. R. and Rajgopal, S. (2005), Economic implications of corporate financial reporting, Journal of Accounting and Economics, 40, 3-73

Guide of good corporate governance practice of the Tunisian enterprises, (2008), Arab Institute of Business Leaders 


\section{MInstitute Macrothink $_{\text {Int }}$}

International Journal of Accounting and Financial Reporting ISSN 2162-3082

Guide of the annual report of the Tunisian enterprises, (2009), Arab Institute of Business Leaders

Hasnan, A. (2005), Corporate voluntary reporting practices in India, The cost and management, 33(5), 73-79

Hassan, O. A. G., Giorgioni, G. and Romilly, P. (2006), The extent of financial disclosure and its determinants in an emerging capital market: the case of Egypt, Accounting, Auditing and Performance Evaluation, 3(1), 41-67

Healy, P. M. and Palepu, K. G. (2001), Information asymmetry, corporate disclosure, and the capital markets: A review of the empirical disclosure literature, Journal of Accounting and Economics, 31, 405-440

Ho, S. S. M. and Wong, K. S. (2001), A study of corporate disclosure practice and effectiveness in Hong Kong, Journal of International Financial Management and Accounting, 12(1), 75-102

Ho, S. S. M. and Wong, K. S. (2004), Investment analysts usage and perceived usefulness of corporate annual reports, Corporate Ownership \& Control, (1), 61-71

Jensen, M. and Meckling, W. (1976), Theory of the firm, managerial behavior, agency costs and ownership structure, Journal of Financial Economics, (3), 305-360

Khlifi, F. And Bouri, A. (2010), Corporate disclosure and firm characteristics: A puzzling relationship, Journal of Accounting - Business \& Management, 17(1), 62-89

Kothari, S., (2000), Role of Financial Reporting in Reducing Financial Risks in the Market, in Eric Rosengren and John Jordan, eds.: Building an Infrastructure for Financial Stability, Federal Reserve Bank of Boston Conference Series No.44:, pp. 89-102

Leventis, S. and Weetman, P. (2004), Voluntary disclosures in an emerging capital market: Some evidence from the Athens stock exchange, Advances in International Accounting, 17, 227-250

Leger, J. Y. (2003) La communication financière, Dunod, France

May, R. G. and Sunden, G. L. (1976), Research for accounting policy: an overview, The Accounting Review, 21

McNally, G. M., Eng, L. H. and Hasseldine, C. R. (1982), Corporate financial reporting in New Zealand: An analysis of user preferences, corporate characteristics and disclosure practices for discretionary information, Accounting and Business Research, 49, 11-20

Michailesco, C. (2000) 'Les rapports annuels : qu'en pensent les analystes financiers, Revue Française de Comptabilité, 325, 24-27

Michailesco, C. (1999), Une étude empirique des déterminants de la qualité de l'information diffusée par les entreprises françaises au cours de la période 1991-1995, ComptabilitéContrôle- Audit, 1, 83-108 


\section{Macrothink}

International Journal of Accounting and Financial Reporting

ISSN 2162-3082

2012, Vol. 2, No. 2

Myburgh, J. E. (2001), The informativeness of voluntary disclosure in the annual reports of listed industrial companies in South Africa, Meditari Acoountancy Research, 9, 199-216

Naser, K. and Nuseibeh, R. (2003), Quality of financial reporting: evidence from the listed Saudi nonfinancial companies, The International Journal of Accounting, 38, 41-69

Nekhili, M. and Fakhfakh, I. (2008), Les relations entre les mécanismes de gouvernement et l'indice de divulgation volontaire d'informations : étude clinique de deux entreprises tunisienne, Revue du Financier, 169, 104-122

Order of the finance minister (the April 7, 2000), "Regulation of the Financial Market Council relates to public offering"

Prencipe, A. (2004), Proprietary costs and determinants of voluntary segment disclosure: Evidence from Italian listed companies, European Accounting Review, 13(2), 319-340

Raffournier, B. (1995), Les besoins d'information des analystes financiers et gestionnaires de fortunes suisses, working paper, HEC-Université de Genève

Schuster, P. and O'Connell, V. (2006), The trend toward voluntary corporate disclosures, Management Accounting Quarterly, 7(2), 1-9

Spence, M. (1973), Job market signaling, The Quarterly Journal of Economics, 87(3), $355-374$

Wagenhofer, A. (1990), Voluntary disclosure with a strategic opponent, Journal of Accounting and Economics, 12, 341-363

Yaich, A. (2006), La nouvelle loi sur le renforcement de la sécurité financière, La revue comptable et financière, $73,38-44$

Yaftian, A. M. and Mirshekary, S. (2005), Perceptions and characteristics of financial statement providers in developing countries: The case of Iran', The Journal of International Accounting, Auditing and Taxation, 14, 33-54

\section{Appendix}

Appendix 1. Questionnaire (distributed to financial analysts and portfolio managers)

\section{$\underline{\text { Respondent personal information }}$}

\section{- You are}

- A portfolio manager working on behalf of a broker.

Which one?

- A financial analyst working on behalf of a broker.

Which one?

- How many annual reports do you read ever year? 
- Diploma

- High technician

- Bachelor of Arts (BA)

- Master of Arts (MA) (specialized or research)

- $\mathrm{PhD}$

- Others (please specify)

- Specialty

- Accounting

- Management

- Finance.

- Economy

- Others (please specify)....

- Professional experience as a financial analyst or portfolio manager

- Less than 5 years<smiles>C1CCC1</smiles>

- Between 5 and 10 years.

- More than 10 years

\section{Question:}

Please indicate how useful each of the following information items which could be disclosed in the annual reports of the non financial companies listed on the (SEST)
$\begin{array}{ll}\text { 1. Not useful at all 2. Little useful } & \end{array}$
3. Somewhat useful
4.Useful
5. Very useful

\begin{tabular}{|c|c|c|c|c|c|c|c|}
\hline \multicolumn{3}{|r|}{ Items of (Botosan, 1997) index } & & & & & \\
\hline 1 & \multicolumn{2}{|c|}{ Background Information } & & & & & \\
\hline & 1 & A statement of corporate goals or objectives is provided & 1 & 2 & 3 & 4 & 5 \\
\hline & 2 & A general statement of corporate strategy is provided & 1 & 2 & 3 & 4 & 5 \\
\hline & 3 & Actions taken during the year to achieve the corporate goals are discussed & 1 & 2 & 3 & 4 & 5 \\
\hline & 4 & Planned actions to be taken in future years are discussed & 1 & 2 & 3 & 4 & 5 \\
\hline & 5 & A time frame for achieving corporate goals is defined & 1 & 2 & 3 & 4 & 5 \\
\hline & 6 & Barriers to entry are discussed & 1 & 2 & 3 & 4 & 5 \\
\hline & 7 & Impact of barriers to entry on current profits are discussed & 1 & 2 & 3 & 4 & 5 \\
\hline & 8 & The competitive environment is discussed & 1 & 2 & 3 & 4 & 5 \\
\hline & 9 & The impact of competition on current profits is discussed & 1 & 2 & 3 & 4 & 5 \\
\hline
\end{tabular}




\section{NI Macrothink}

International Journal of Accounting and Financial Reporting

ISSN 2162-3082

2012, Vol. 2, No. 2

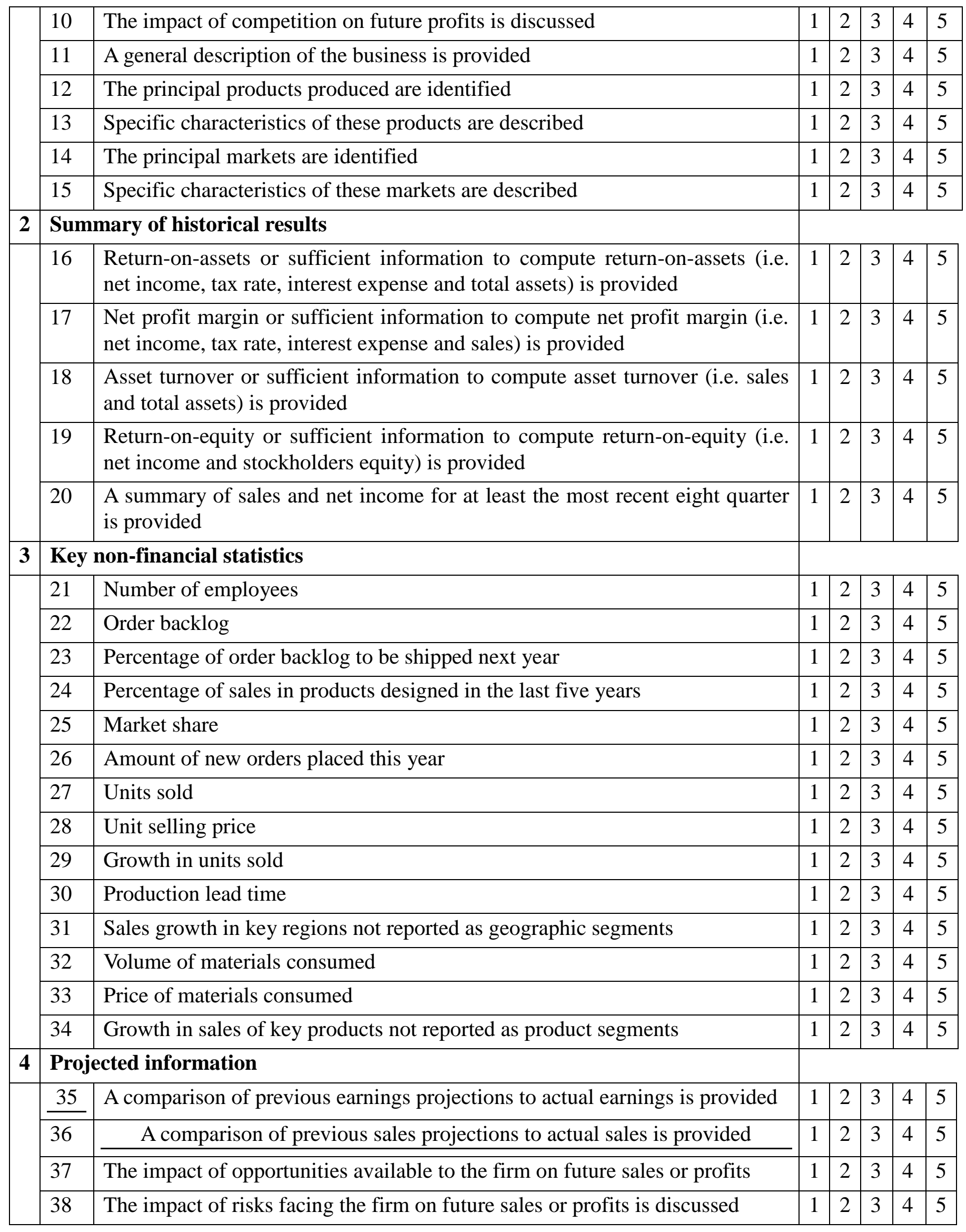




\section{Macrothink}

International Journal of Accounting and Financial Reporting

ISSN 2162-3082

2012, Vol. 2, No. 2

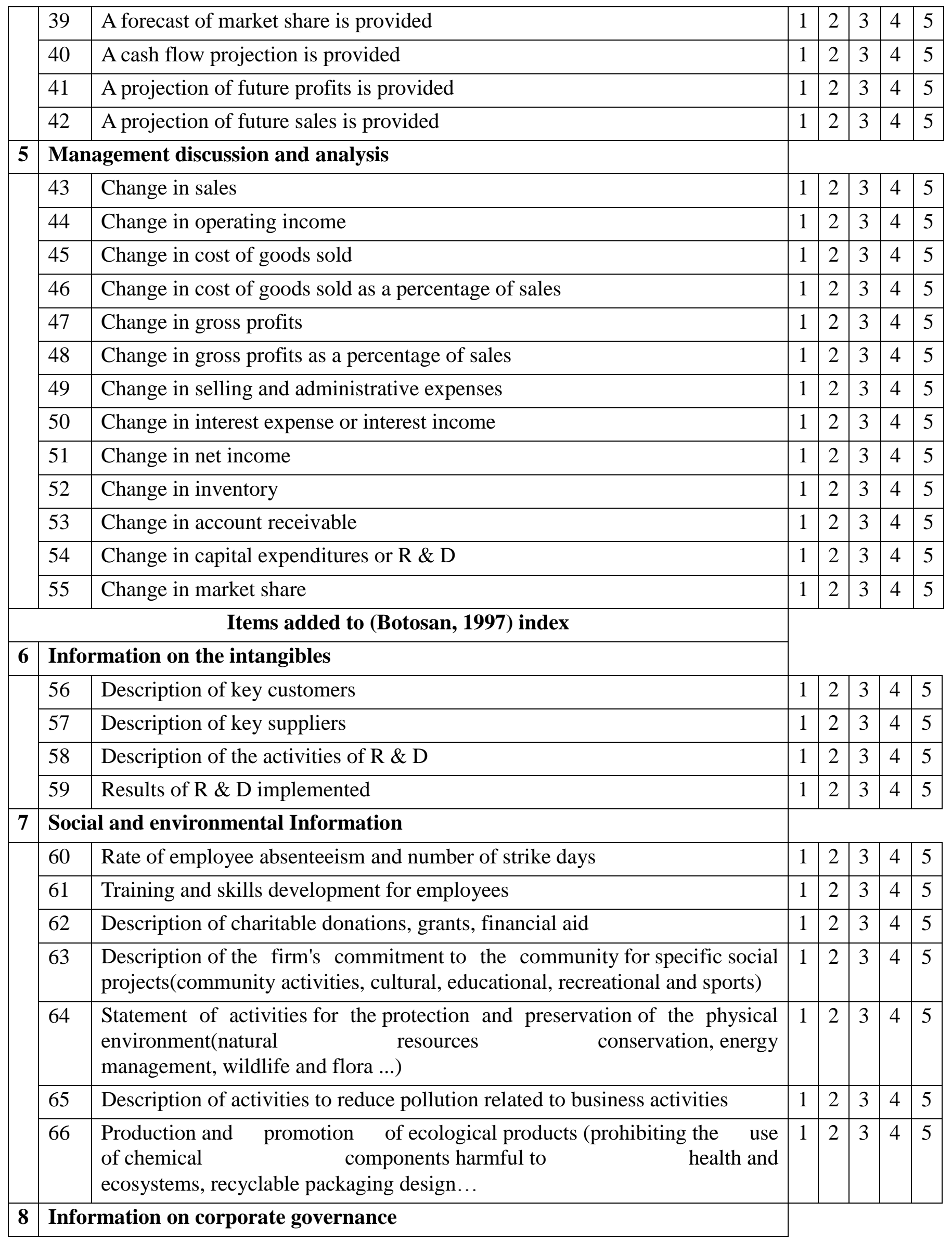




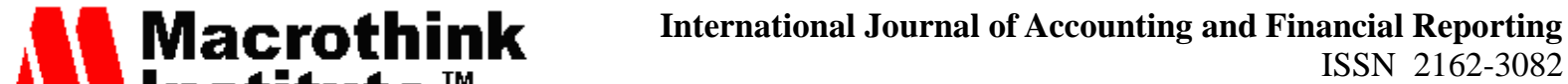 2012, Vol. 2, No. 2}

\begin{tabular}{|l|l|l|l|l|l|l|}
\hline 67 & Ownership structure (major shareholders) & 1 & 2 & 3 & 4 & 5 \\
\hline 68 & Percentage ownership by major shareholders & 1 & 2 & 3 & 4 & 5 \\
\hline 69 & Composition of the Board & 1 & 2 & 3 & 4 & 5 \\
\hline 70 & The mandates of the administrators & 1 & 2 & 3 & 4 & 5 \\
\hline 71 & Profile of administrators & 1 & 2 & 3 & 4 & 5 \\
\hline 72 & The frequency of meetings of the Board & 1 & 2 & 3 & 4 & 5 \\
\hline
\end{tabular}

Appendix 2. Correlation Matrix

\begin{tabular}{|c|c|c|c|c|}
\hline & & & RANK of UPA & RANK of DDS \\
\hline \multirow{6}{*}{$\begin{array}{l}\text { Spearman's } \\
\text { rho }\end{array}$} & \multirow[t]{3}{*}{ RANK of UPA } & Correlation Coefficient & 1,000 & 0,202 \\
\hline & & Sig. (2-tailed) & & 0,089 \\
\hline & & $\mathrm{N}$ & 72 & 72 \\
\hline & \multirow[t]{3}{*}{ RANK of DDS } & Correlation Coefficient & 0,202 & 1,000 \\
\hline & & Sig. (2-tailed) & 0,089 & \\
\hline & & $\mathrm{N}$ & 72 & 72 \\
\hline
\end{tabular}

